\title{
Wheat bran extracts: a potent source of natural antioxidants for the stabilization of canola oil
}

\author{
By Shahzad Ali Shahid Chatha, ${ }^{* 1,2}$ Abdullah ljaz Hussain, ${ }^{2}$ Jawad-ur-Rehman Bajwa, ${ }^{1}$ \\ Syed Tufail Hussain Sherazi ${ }^{3}$ and Aiza Shaukat
}

1 Department of Chemistry and Biochemistry, University of Agriculture, Faisalabad-38040, Pakistan.
${ }^{2}$ Departments of Chemistry and Industrial Chemistry, GC University, Faisalabad-38000, Pakistan.
${ }^{3}$ National Centre of Excellence of Analytical Chemistry, University of Sindh, Jamshoro, Pakistan

( ${ }^{\star}$ Corresponding author: chatha222@gmail.com)

\section{RESUMEN}

Extracto de salvado de trigo: una potente fuente de antioxidantes naturales para la estabilización del aceite de canola.

En el presente trabajo la actividad antioxidante de diferentes extractos obtenidos con disolventes del salvado de trigo (var. Inqalab 91) fue evaluada mediante diferentes ensayos antioxidantes y aceite de canola como substrato de oxidación. Las muestras de salvado fueron extraídas con metanol y acetona al $80 \%$ y al $100 \%$. La evaluación preliminar de la actividad antioxidante de los extractos de metanol y de acetona al $80 \%$ y $100 \%$ fue hecha mediante la medida del $\%$ de inhibición de la peroxidación en un sistema con ácido linoleico, el contenido total de fenoles (TPC) y el blanqueamiento de $\beta$-carotene en un sistema con ácido linoleico. Además, las muestras de aceite de canola fueron estabilizadas con extractos crudos concentrados y sometidos a envejecimiento ambiental (6 meses). La extensión del deterioro oxidativo fue seguido mediante la medida del índice de peróxidos, de $p$-anisidine y de dienos y trienos congugados. Los resultados de las muestras almacenadas a temperatura ambiente revelaron una significativa mejora en los parámetros de oxidación. El orden general de actividad antioxidante de los extractos, determinados por varios métodos antioxidantes, fue el siguiente: extracto metanólico $80 \%$ > extracto metanólico $100 \%$ > extracto acetona $80 \%$ > extracto acetona $100 \%$. Los resultados de los análisis demuestran que los extractos de salvado de trigo autóctono de Pakistán son una fuente viable de antioxidantes naturales y podría ser usado en aplicaciones comerciales y neutracéticas.

PALABRAS-CLAVE: Almacenamiento ambiente - Antioxidante natural - $\beta$-Carotene - Porcentaje de inhibición Salvado de arroz - TPC

\section{SUMMARY}

Wheat bran extracts: a potent source of natural antioxidants for the stabilization of canola oil.

In the present work, the antioxidant activity of different solvent extracts of wheat (var. Inqalab 91) bran was evaluated following different antioxidant assays using canola oil as the oxidation substrate. The bran samples were extracted with $80 \%$ and $100 \%$ methanol and acetone. A preliminary assessment of the antioxidant activity of the 80 and $100 \%$ acetone and methanolic extracts of wheat bran was done by the measurement of \% inhibition of peroxidation in a linoleic acid system, total phenolic contents (TPC) and bleachability of $\beta$-carotene in the linoleic acid system. Additionally, the canola oil samples were stabilized with crude concentrated extracts and subjected to ambient aging (6 months). The extent of oxidative deterioration was followed by the measurement of peroxide-, $p$-anisidine-, conjugated dienes-, and trienes- values. The results of ambient stored samples revealed a significant improvement in these oxidation parameters. The overall order of antioxidant activity of the extracts as determined by various antioxidant assays was determined to be; $80 \%$ methanolic extract $>100 \%$ methanolic extract $>80 \%$ acetone extracts $>100 \%$ acetone extract. The results of the present comprehensive analysis demonstrate that extracts of the wheat bran indigenous to Pakistan are a viable source of natural antioxidants and might be exploited for commercial and neutraceutical applications.

KEY-WORDS: Ambient storage - $\beta$-carotene - Natural Antioxidant - Percent Inhibition - TPC - Wheat Bran.

\section{INTRODUCTION}

Severe oxidative stress, resulting from an imbalance between the antioxidant defense system and the formation of reactive oxygen species, may damage vital membrane lipids, proteins, DNA, and carbohydrates. The damage may cause cell injury and death and exacerbate the development of several age-related chronic diseases including cancer and heart disease (Baublis et al., 2000; Sultan et al., 2008). It has been widely accepted that diet may significantly influence human health and quality of life (Anwar et al., 2010).

In comparison to the chemical compounds of an organic nature, lipids are more prone to an auto-oxidation reaction by oxygen. The addition of synthetic antioxidants to food fats and oils is one of the most effective ways to prevent oxidation and the development of off-flavors. The most widely used synthetic antioxidants, butylated hydroxy toluene (BHT), butylated hydroxy anisole (BHA), ter-butyl hydroxy quinoline (TBHQ), propyl gallate and dodecyl gallate are suspected to cause safety concerns because of their perceived carcinogenic effects (Jeong et al., 2004). 
Novel natural antioxidants with desired physiochemical properties are in high demand for their application as neutraceuticals in disease prevention and health promotion (Zhou et al., 2004). There is an increasing interest on the part of the food industry and preventive medicines to replace synthetic antioxidants with those of safer and more natural origins. Recently, a great deal of attention has been given to the exploration of natural antioxidants as these are considered to pose no health risk to consumers (Shahidi, 1997b; Chatha et al., 2006b). Cereal antioxidants have gained substantial interest in the past years. An increasing consumption of cereals also increases the intake of components that have beneficial health effects. Further, there is a demand to find effective natural antioxidants to replace synthetic ones, which has also added to the amount of research done on cereal antioxidants such as tocopherols, tocotrienols, and phenolic acids. Tocopherols as well as other bioactive components (phytosterols, folates, lignans, and alk (en) ylresorcinols) have beeen shown to be located on the outer parts of the cereal kernel, especially the bran (Nystrom et al., 2005; Mariod et al., 2010).

In Pakistan wheat was cultivated on 8.33 million hectares during the year 2004-05 and expected production would be around 22.00 million tones. The variety Inqilab-91 is still grown as the main variety on a large acreage of about 60 to 70 per cent of the total area under wheat cultivation in the country. Its genetic resistance against yellow rust has broken down, creating an alarming situation due to the lack of availability of seeds of other improved varieties. The planting time for this variety is Nov.10 to Dec.15. (www.infopak.gov.pk/news/ appnews/ appnews2005/app.htm).

Increasing evidence indicates that wheat and wheat-based food products contain significant levels of natural antioxidants, which may provide health benefits to consumers in addition to general nutrients and energy (Abdel-Aal and Hucl, 2003; Zhou and $\mathrm{Yu}$, 2004). Wheat is an important agricultural commodity and dietary component across the world. Previous studies showed that wheat varieties vary in their antioxidant properties; total phenolic contents (TPCs), phenolic acid compositions, and carotenoid profiles (Zhou and Yu, 2004).

A recent study of Swiss red wheat grain and fractions showed that phenolic antioxidants are concentrated in the aleurone fraction of wheat bran and further micronization increased the availability of antioxidants in the aleurone samples (Zhou et al., 2004). Several phenolic acids have been detected in wheat and wheat fractions. Ferulic acid was the predominate phenolic acid in Trego wheat bran produced in Colorado and accounted for 59$60 \%$ of the total phenolic acids on a per weight basis, along with significant levels of syringic, p-hydroxybenzoic, vanillic, and coumaric acids at a concentration range of $4-33 \mu \mathrm{g} / \mathrm{g}$ bran (Zhou and $\mathrm{Yu}, 2004)$. Although a significant number of reports are available on the nutritional and antioxidant attributes of wheat bran, no work is reported regarding the antioxidant potential of indigenously available wheat bran in Pakistan or its antioxidant activity. As Pakistan is an agricultural country and a large quantity of the wheat bran is produced annually as agricultural waste, it is only used as animal feed in Pakistan. In view of the beneficial uses and the vital role natural antioxidants can play in human health, a great demand exists to exploit additional plants and agricultural wastes as a potential source of natural antioxidants. The present research work was aimed at investigating the antioxidant activity of locally available wheat bran using different antioxidant assays and canola oil as oxidation substrate.

\section{MATERIALS AND METHODS}

\subsection{Samples and Reagents}

Samples of freshly milled Inqalab-91 wheat (Triticum aestivum L.) bran were collected directly from local agricultural household sources in polyethylene bags. These bags were made air tight and stored at $4{ }^{\circ} \mathrm{C}$ in a cooler. Refined, bleached and deodorized (RBD) canola oil was obtained from United Industries Pvt. Limited, Kashmir Road, Faisalabad, Pakistan. Butylated hydroxytoluene (BHT), $\beta$-carotene (type I; synthetic 95\%), linoleic acid and tween 40 (polyoxyethylenesorbitan monopalmitate) were purchased from Sigma Chemical Co. (St. Louis, MO). All other chemicals and reagents were of the analytical grade from $\mathrm{E}$. Merck and Sigma-Aldrich.

\subsection{Extraction of Wheat Bran}

The powdered sample of wheat bran $(20 \mathrm{~g})$ was separately mixed with $200 \mathrm{~mL}$ of $100 \%$ and $80 \%$ Methanol and acetone (each) in conical flasks. Extraction was executed in an electric shaker for 48 hours at ambient temperature. Each of the extracts was filtered and freed from moisture with $\mathrm{Na}_{2} \mathrm{SO}_{4}$. The solvents were distilled off under reduced pressure using an Eyela, Rotary Vacuum Evaporator N.N. The series was fitted with an Aspirator and a Digital Water Bath B-651, Japan. The crude concentrated extracts were stored under refrigeration $\left(4^{\circ} \mathrm{C}\right)$ until further analysis as reported by Perumal and Becker (2003).

\subsection{Antioxidant Activity Evaluation}

A preliminary evaluation of the antioxidant activity of the crude concentrated extracts was carried out using the rapid antioxidant assays.

\subsection{Total Phenolic Content (TPC)}

The TPCs of wheat bran extracts were determined using the Folin-Ciocalteu reagent method as reported 
by Chatha et al. (2006a). Briefly, the reaction mixture contained $50 \mu \mathrm{l}$ of wheat bran extracts, $3 \mathrm{~mL}$ of pure water, $250 \mu \mathrm{l}$ of the freshly prepared Folin-Ciocalteu reagent and $0.75 \mathrm{~mL}$ of $20 \%$ sodium carbonate. After $2 \mathrm{~h}$ of reaction at ambient temperature, the absorbance at $765 \mathrm{~nm}$ was measured using a spectrophotometer (Hitachi, U-2001, model 1210032 Spectrometer). The Folin-Ciocalteu reagent was prepared by refluxing a mixture of sodium molybdate, sodium tungstate, $85 \%$ phosphoric acid, and concentrated hydrochloric acid for $10 \mathrm{~h}$ and followed by reacting with lithium sulfate and oxidizing with a few drops of bromine. The resulting solution was filtered and ready for testing. The TPCs were calculated as GAE on a dry mass basis.

\subsection{Antioxidant Activity Determination in a Linoleic Acid System}

The antioxidant activity of the bran extracts was determined following the reported method of Osawa and Namiki (1981). The extracts were added to a solution mixture of linoleic acid $(0.13 \mathrm{ml}), 99.85$ ethanol $(10 \mathrm{ml})$ and $0.2 \mathrm{M}$ sodium phosphate buffer $(\mathrm{pH} 7,10 \mathrm{ml})$. The mixture was diluted to $25 \mathrm{ml}$ with distilled water. The solution was incubated at $40^{\circ} \mathrm{C}$ and the degree of oxidation was measured according to the thiocyanate method of Yen et al. (2000) with $10 \mathrm{ml}$ of ethanol (75\%), $0.2 \mathrm{ml}$ of an aqueous solution of ammonium thiocyanate $(30 \%), 0.2 \mathrm{ml}$ of sample solution and $0.2 \mathrm{ml}$ of ferrous chloride $\left(\mathrm{FeCl}_{2}\right)$ solution $(20 \mathrm{mM}$ in $3.5 \%$ $\mathrm{HCl}$ ) added sequentially. After $3 \mathrm{~min}$ of stirring, the absorption values of the mixtures measured at $500 \mathrm{~nm}$ were taken as peroxide contents. A control was performed with linoleic acid (without extract). A synthetic antioxidant, Butylated Hydroxytoluene (BHT), was also used as a positive control. The percent inhibition of linoleic acid peroxidation, 100 - [(Abs. increase of sample at $360 \mathrm{~h} / \mathrm{Abs}$. An increase of control at $360 \mathrm{~h}) \times 100]$, was calculated to express antioxidant activity.

\subsection{Antioxidant Activity Determination in a $\beta$-Carotene Linoleic Acid System}

Two $\mathrm{mL}$ of a solution of $\beta$-carotene in chloroform (1 $\mathrm{mg} / \mathrm{mL}$ ) were added to a flask containing 40 $\mathrm{mg}$ of linoleic acid and $400 \mathrm{mg}$ of tween 40 . The chloroform was removed by rotary vacuum evaporator at $45^{\circ} \mathrm{C}$ for $4 \mathrm{~min}$ and $100 \mathrm{~mL}$ of distilled water were added slowly to the semisolid residue with vigorous agitation to form an emulsion. A $5 \mathrm{~mL}$ aliquot of the emulsion was added to a tube containing $0.2 \mathrm{~mL}$ of the antioxidant solution (500 $\mathrm{mg} / \mathrm{L}$ ) and the absorbance was measured at 470 $\mathrm{nm}$ by spectrophotometer (Hitachi, U-2001, model 121-0032 spectrometer) immediately, against a blank, (consisting of the emulsion without $\beta$-carotene). The tubes were placed in a water bath at $50^{\circ} \mathrm{C}$, and the absorbance measurements were conducted again for $120 \mathrm{~min}$. at $5 \mathrm{~min}$ intervals.
All measurements were carried out in triplicate. The antioxidant activity (A.A) of the extract was evaluated in terms of the bleaching of betacarotene using the following formula: $A A=\left[1-\left(A_{0}-A_{t}\right)\right.$ / $\left.\left(A_{0}^{\prime}-A_{t}^{\prime}\right)\right] \times 100$.

Where $A_{0}$ and $A_{t}$ are the absorbance values measured at zero time of the incubation for test sample and control, respectively and $A_{0}^{\prime}$ and $A_{t}^{\prime}$ are the absorbance measured in the test sample and control respectively after incubation for $120 \mathrm{~min}$ (Perumal and Becker, 2003).

\subsection{Antioxidant activity evaluation using canola oil as oxidation substrate}

\section{Stabilization of Oil Samples}

The crude concentrated extracts were added to RBD canola oil. The mixtures were stirred for 30 min. at $50^{\circ} \mathrm{C}$ for uniform dispersion. Control samples (without the addition of any antioxidant extract) were also prepared under the same conditions.

\section{Ambient Storage Test and Measurement of Oxidation}

Three replicates of canola oil treatments along with controls were carried out. In an ambient storage test the samples were stored for six months at room temperature. Analysis was done periodically after every 15 days. The oxidative deterioration level was followed by the measurement of peroxide value (PV), conjugated dienes and trienes contents and $p$ - anisidine value. The determination of $\mathrm{PV}$ was made according to the IUPAC standard method (IUPAC, 1987). Specific extinctions at 232 and $268 \mathrm{~nm}$ were determined using spectrophotometer (Hitachi, U-2001, model 121-0032 Spectrometer). Samples were diluted with iso-octane to bring the absorbance within limits $(0.2-0.8)$ and $\left({ }^{1 \%} \varepsilon_{1 \mathrm{~cm}(\lambda)}\right)$ was calculated following the method of IUPAC (1987). The $p$-anisidine value was calculated according to the IUPAC standard method. The oil samples were allowed to react with $p$-anisidine to produce a colored compound and the absorbance values were noted at $350 \mathrm{~nm}$ by spectrophotometer (Hitachi, U-2001, model 121-0032 spectrometer) following the method of IUPAC (1987).

\section{RESULTS AND DISCUSSION}

\subsection{Preliminary Antioxidant Activity Evaluations}

In the present study two solvent systems i.e. 100 and $80 \%$ methanol and acetone were used to extract wheat bran antioxidants for the evaluation of antioxidative activity. The results obtained were compared to examine the extraction efficacy of each of the solvent systems used.

Fig. 1 shows the results of the $\beta$-carotene linoleic acid system assay. The antioxidant activity 


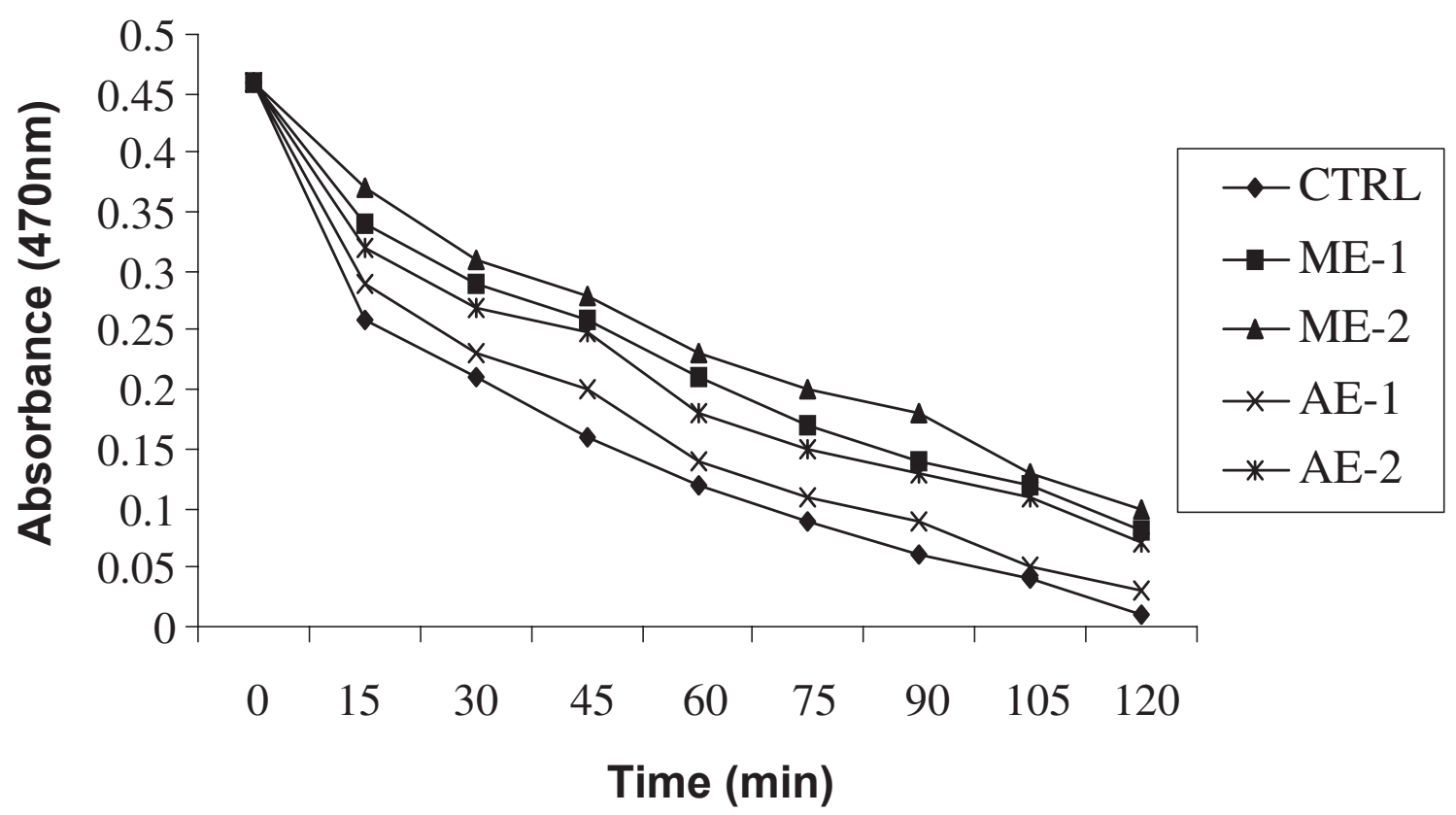

Figure 1

Antioxidant activity of various solvent extracts of wheat bran in a beta-carotene linoleic acid system. Ctr: Control sample without wheat bran extract. M.E-1: 100\% Methanolic Extract. M.E-2: 80\% Methanolic Extract. A.E-1: 100\% Acetone Extract. A.E-2: $80 \%$ Acetone Extract.

of wheat bran extracts was determined in terms of the bleaching of the $\beta$-carotene color. The decline in absorbance in the case of the control was found to be rapid compared to the samples with extracts, showing the antioxidant activity of the extracts. The overall decline rate in absorbance among the investigated extracts was as follows: $\mathrm{AE}-1>\mathrm{AE}-2>\mathrm{ME}-1>\mathrm{ME}-2$. In this study the highest antioxidant activity was exhibited by $80 \%$ methanolic extract of wheat bran as indicated by smallest decline in absorbance in ME-2. The rapid decline in absorbance for sample AE-1 showed the least antioxidant activity of $100 \%$ acetone extract of wheat bran. As methanolic extracts of wheat bran have exhibited higher antioxidant activity, so it could be possible to declare that methanol is a potent antioxidant extract for wheat bran. The slower rate of oxidation of $\beta$-carotene might be due to the presence of polyphenolics, the natural antioxidants in the wheat bran extracts (Chatha et al., 2006a; Amarowicz et al., 2001). Kim et al. (2006) has reported the same results of the commercial white bran indicating that the methanol extractable fractions of bran inhibited peroxidation slightly better than BHT during the first $60 \mathrm{~min}$.

The acetone and methanolic extracts of wheat bran were examined and compared for their TPCs expressed as gallic acid equivalents (GAE) are shown in Figure 2. The values for TPCs of the extracts of wheat bran were 2.6, 2.9, 2.1 and 2.4 $\mathrm{mg} / \mathrm{g}$ for samples of ME-1, ME-2, AE-1, and AE2 , respectively. The highest TPC of $2.9 \mathrm{mg} \mathrm{GE} / \mathrm{g}$ bran was detected in the $80 \% 600 p p m$ methanolic extract of wheat bran, while $100 \% 600 p p m$ acetone extract of wheat bran had the lowest TPC value of $2.1 \mathrm{mg} \mathrm{GE} / \mathrm{g}$ bran. Iqbal et al. (2005) reported that the estimation of TPC is a good measurement of the antioxidant activity of the extracts. The TPCs estimated in the present study are comparable to those of the "Akron" wheat bran, investigated by Zhou and Yu (2004). Zhou and Yu (2004) have also reported wheat bran as a potential source of natural antioxidants, suggesting the exploitation of wheat bran as a viable source of antioxidants for neutraceuticals and functional foods.

The antioxidant activity of different extracts of wheat bran in a linoleic acid system was measured in terms of inhibition of peroxidation. Figure 3 shows the results of \% inhibition of the peroxidation of linoleic acid after an incubation period of 13 days. At a concentration of $0.2 \mathrm{mg} / \mathrm{mL}$, the inhibition of peroxidation of linoleic acid was observed as, 92, $81,90,73$, and $78 \%$ for the samples BHT, ME-1, $\mathrm{ME}-2, \mathrm{AE}-1$ and $\mathrm{AE}-2$ respectively. $\mathrm{ME}-2$ was found to show higher inhibition of peroxidation (90\%) in a linoleic acid system, thus indicating the highest antioxidant activity among the extracts. The AE-1 showed the least inhibition of peroxidation. This \% inhibition of oxidation as exhibited by wheat bran extracts might be due to the presence of phenolics. Oryeneho and Hettiarachchy (1992) had reported that the phenolic contents of various agriculture wastes contained potential activity against the linoleic acid peroxidation system.

\subsection{Antioxidant Activity Using Canola Oil as Oxidation Substrate}

Table 1 shows the relative increase in peroxide value (PV) of the canola oil treatments under ambient aging. A typical pattern in the rise of $P V$ was observed for almost all the oil treatments. 


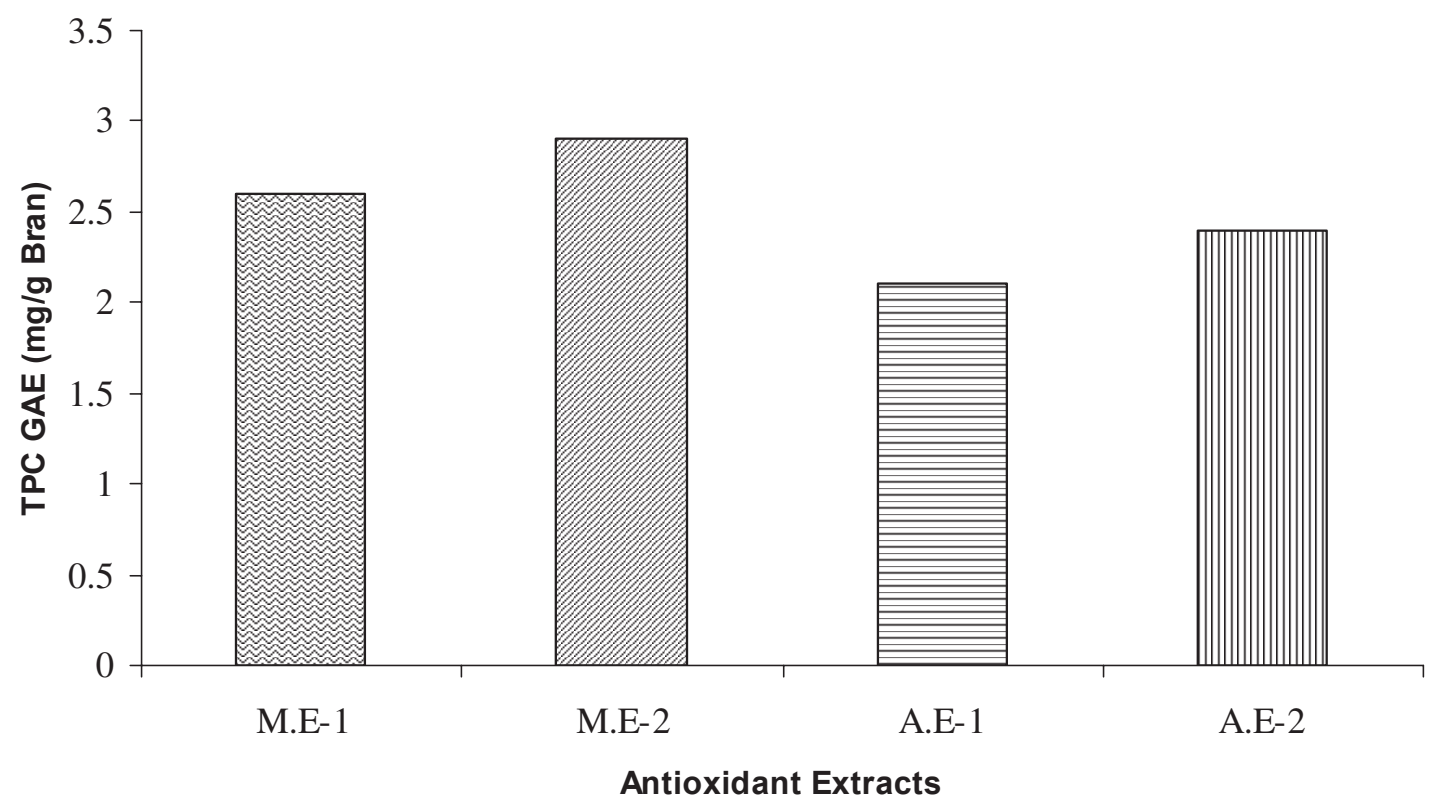

Figure 2

Total phenolic contents (TPC) of wheat bran extracts (mg/g). M.E-1: 100\% Methanolic Extract. M.E-2: 80\% Methanolic Extract. A.E-1: 100\% Acetone Extract. A.E-2: $80 \%$ Acetone Extract.

Table 1

Relative increase in PV (meq/kg) of canola oil stabilized with wheat bran extracts at ambient storage

\begin{tabular}{cccccc}
\hline IPD & Ctrl & Canola-M.E1 & Canola-M.E2 & Canola-A.E1 & Canola-A.E2 \\
\hline 00 & $0.5 \pm 0.04^{\mathrm{a}}$ & $0.5 \pm 0.03^{\mathrm{a}}$ & $0.5 \pm 0.02^{\mathrm{a}}$ & $0.5 \pm 0.03^{\mathrm{a}}$ & $0.5 \pm 0.02^{\mathrm{a}}$ \\
15 & $0.9 \pm 0.22^{\mathrm{ab}}$ & $0.7 \pm 0.06^{\mathrm{a}}$ & $0.7 \pm 0.05^{\mathrm{a}}$ & $0.9 \pm 0.07^{\mathrm{b}}$ & $0.8 \pm 0.05^{\mathrm{a}}$ \\
30 & $2.0 \pm 0.19^{\mathrm{b}}$ & $1.5 \pm 0.10^{\mathrm{a}}$ & $1.5 \pm 0.11^{\mathrm{a}}$ & $1.8 \pm 0.14^{\mathrm{ab}}$ & $1.7 \pm 0.11^{\mathrm{a}}$ \\
45 & $3.2 \pm 0.26^{\mathrm{c}}$ & $2.4 \pm 0.21^{\mathrm{a}}$ & $2.3 \pm 0.20^{\mathrm{a}}$ & $2.8 \pm 0.21^{\mathrm{b}}$ & $2.6 \pm 0.21^{\mathrm{ab}}$ \\
60 & $4.3 \pm 0.31^{\mathrm{b}}$ & $3.2 \pm 0.30^{\mathrm{a}}$ & $3.2 \pm 0.27^{\mathrm{a}}$ & $3.8 \pm 0.32^{\mathrm{ab}}$ & $3.5 \pm 0.24^{\mathrm{a}}$ \\
75 & $5.4 \pm 0.30^{\mathrm{b}}$ & $4.0 \pm 0.31^{\mathrm{a}}$ & $3.9 \pm 0.31^{\mathrm{a}}$ & $4.7 \pm 0.40^{\mathrm{ab}}$ & $4.4 \pm 0.36^{\mathrm{a}}$ \\
\hline
\end{tabular}

Values (mean \pm SD) are average of duplicate samples analyzed individually in triplicate. IPD: Incubation period in days. Ctrl.: Control sample (without wheat bran extract.). Canola-M.E1: Canola oil samples stabilized with 600ppm 100\% Methanolic Extract. Canola-M.E2: Canola oil samples stabilized with 600ppm 80\% Methanolic Extract. Canola-A.E1: Canola oil samples stabilized with 600ppm 100\% Acetone Extract. Canola-A.E2: Canola oil samples stabilized with 600ppm $80 \%$ Acetone Extract. Different letters in superscript in the same row represent significant $(p<0.05)$ difference.

The control had the highest PV among all the oil treatments, showing the highest degree of oxidation. A slow rise in the PV of Canola-ME1, CanolaME2, Canola-AE1 and Canola-AE2 as compared with that of control (ctrl) clearly indicated a good antioxidant activity of extracts. Methanolic extracts of the wheat bran were found to be more effective in retarding the PV of canola oil as indicated by a slow rise in the hydroperoxide product formation in Canola-ME1 and Canola-ME2 as compared with those of the acetone extracts of wheat bran which retarded $\mathrm{PV}$ less, depicted by the high amount of formation of hydroperoxide products in Canola$A E 1$ and Canola-AE2 oil treatments. The results of $\mathrm{PV}$ indicated that the $80 \%$ methanolic extract was more effective than the $100 \%$ methanolic extract of wheat bran. The PV, which measures hydroperoxide products in oils, is a good indicator of the primary oxidation state of oils (McGinely,
1991). Anwar et al. (2003) had also investigated the activity of different natural extracts in retarding the PV of corn oil samples stored under ambient and accelerated conditions. A similar trend in retarding the PV during the stabilization of sunflower oil at accelerated storage using natural extracts of rice bran had been reported by Chatha et al. (2006b).

Tables 2-3 show the conjugated dienes (CD) and conjugated trienes (CT) contents for the stabilized and control samples of canola oil. It was observed that $C D$ and $C T$ contents went on increasing as a function of time in a linear fashion. All the extracts showed good antioxidant activity as exhibited by a lower rate of formation of $C D$ and CT as compared with those of the control samples. The $80 \%$ methanolic extract was found to be the most effective among all the extracts, as indicated by the lowest rise in CD and CT of Canola-ME2 (2.71 \& 1.57). The highest values (3.59\& 2.06) of 


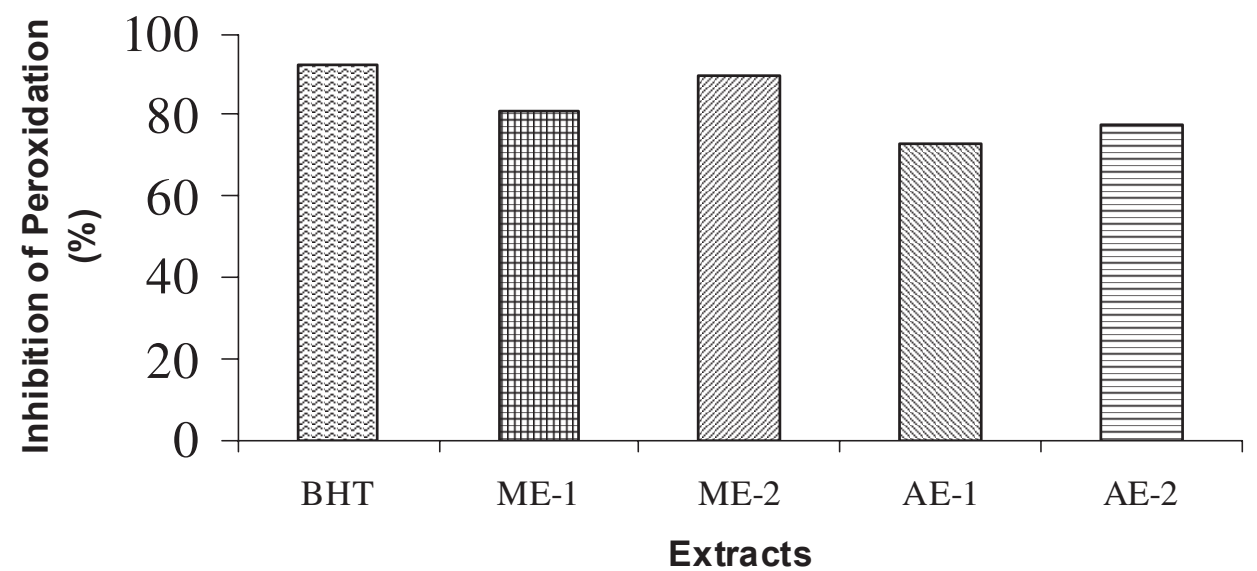

Figure 3

Antioxidant activity of various solvent extracts of wheat bran in a linoleic acid system. BHT: Butylated Hydroxy Toluene. M.E-1: 100\% Methanolic Extract. M.E-2: 80\% Methanolic Extract. A.E-1: 100\% Acetone Extract. A.E-2: $80 \%$ Acetone Extract.

Table 2

Relative increase in conjugated dienes $\left(\varepsilon_{1 \mathrm{~cm}}\left(\lambda_{232 \mathrm{~nm}}\right)\right)$ of canola oil stabilized with wheat bran extracts at ambient storage

\begin{tabular}{cccccc}
\hline IPD & Ctrl & Canola-M.E1 & Canola-M.E2 & Canola-A.E1 & Canola-A.E2 \\
\hline 00 & $1.25 \pm 0.08^{\mathrm{a}}$ & $1.25 \pm 0.08^{\mathrm{a}}$ & $1.25 \pm 0.05^{\mathrm{a}}$ & $1.25 \pm 0.06^{\mathrm{a}}$ & $1.25 \pm 0.08^{\mathrm{a}}$ \\
15 & $1.96 \pm 0.12^{\mathrm{c}}$ & $1.37 \pm 0.10^{\mathrm{a}}$ & $1.29 \pm 0.09^{\mathrm{a}}$ & $1.77 \pm 0.10^{\mathrm{b}}$ & $1.61 \pm 0.12^{\mathrm{b}}$ \\
30 & $2.94 \pm 0.13^{\mathrm{c}}$ & $1.98 \pm 0.12^{\mathrm{a}}$ & $1.86 \pm 0.13^{\mathrm{a}}$ & $2.52 \pm 0.20^{\mathrm{b}}$ & $2.33 \pm 0.12^{\mathrm{b}}$ \\
45 & $3.47 \pm 0.21^{\mathrm{c}}$ & $2.29 \pm 0.19^{\mathrm{a}}$ & $2.14 \pm 0.16^{\mathrm{a}}$ & $2.80 \pm 0.16^{\mathrm{b}}$ & $2.61 \pm 0.20^{\mathrm{b}}$ \\
60 & $3.82 \pm 0.24^{\mathrm{c}}$ & $2.59 \pm 0.13^{\mathrm{a}}$ & $2.44 \pm 0.14^{\mathrm{a}}$ & $3.16 \pm 0.21^{\mathrm{b}}$ & $2.88 \pm 0.13^{\mathrm{b}}$ \\
75 & $4.30 \pm 0.33^{\mathrm{c}}$ & $2.86 \pm 0.14^{\mathrm{a}}$ & $2.71 \pm 0.20^{\mathrm{a}}$ & $3.59 \pm 0.23^{\mathrm{b}}$ & $3.30 \pm 0.27^{\mathrm{b}}$ \\
\hline
\end{tabular}

Values (mean $\pm \mathrm{SD}$ ) are average of duplicate samples analyzed individually in triplicate. IPD: Incubation period in days. Ctrl: Control sample (without wheat bran extract.). Canola-M.E1: Canola oil samples stabilized with 600ppm 100\% Methanolic Extract. Canola-M.E2: Canola oil samples stabilized with 600ppm 80\% Methanolic Extract. Canola-A.E1: Canola oil samples stabilized with 600ppm 100\% Acetone Extract. Canola-A.E2: Canola oil samples stabilized with 600ppm 80\% Acetone Extract. Different letters in superscript in the same row represent significant $(p<0.05)$ difference.

Table 3

Relative increase in conjugated trienes $\left(\varepsilon_{1 \mathrm{~cm}}\left(\lambda_{268 \mathrm{~nm}}\right)\right)$ of canola oil stabilized with wheat bran extracts at ambient storage

\begin{tabular}{cccccc}
\hline IPD & CtrI & Canola-M.E1 & Canola-M.E2 & Canola-A.E1 & Canola-A.E2 \\
\hline 00 & $0.08 \pm 0.01^{\mathrm{a}}$ & $0.08 \pm 0.01^{\mathrm{a}}$ & $0.08 \pm 0.01^{\mathrm{a}}$ & $0.08 \pm 0.01^{\mathrm{a}}$ & $0.08 \pm 0.01^{\mathrm{a}}$ \\
15 & $0.99 \pm 0.01^{\mathrm{c}}$ & $0.74 \pm 0.03^{\mathrm{a}}$ & $0.68 \pm 0.03^{\mathrm{b}}$ & $0.93 \pm 0.04^{\mathrm{b}}$ & $0.85 \pm 0.04^{\mathrm{b}}$ \\
30 & $1.59 \pm 0.11^{\mathrm{c}}$ & $0.92 \pm 0.04^{\mathrm{a}}$ & $0.86 \pm 0.04^{\mathrm{a}}$ & $1.33 \pm 0.09^{\mathrm{b}}$ & $1.12 \pm 0.07^{\mathrm{b}}$ \\
45 & $1.74 \pm 0.10^{\mathrm{c}}$ & $0.99 \pm 0.05^{\mathrm{a}}$ & $0.89 \pm 0.06^{\mathrm{a}}$ & $1.49 \pm 0.12^{\mathrm{b}}$ & $1.27 \pm 0.09^{\mathrm{b}}$ \\
60 & $1.94 \pm 0.12^{\mathrm{c}}$ & $1.23 \pm 0.10^{\mathrm{a}}$ & $1.17 \pm 0.06^{\mathrm{a}}$ & $1.66 \pm 0.12^{\mathrm{b}}$ & $1.47 \pm 0.10^{\mathrm{b}}$ \\
75 & $2.90 \pm 0.22^{\mathrm{c}}$ & $1.64 \pm 0.11^{\mathrm{a}}$ & $1.57 \pm 0.13^{\mathrm{a}}$ & $2.06 \pm 0.16^{\mathrm{b}}$ & $1.83 \pm 0.12^{\mathrm{b}}$ \\
\hline
\end{tabular}

Values (mean \pm SD) are average of duplicate samples analyzed individually in triplicate. IPD: Incubation period in days. Ctrl.: Control sample (without wheat bran extract.). Canola-M.E1: Canola oil samples stabilized with 600ppm 100\% Methanolic Extract. Canola-M.E2: Canola oil samples stabilized with 600ppm 80\% Methanolic Extract. Canola-A.E1: Canola oil samples stabilized with 600ppm 100\% Acetone Extract. Canola-A.E2: Canola oil samples stabilized with 600ppm 80\% Acetone Extract. Different letters in superscript in the same row represent significant $(p<0.05)$ difference.

$\mathrm{CD}$ and $\mathrm{CT}$ of Canola-AE1 demonstrated the least antioxidant potential of acetone extract of wheat bran. Conjugated dienes (CD) and conjugated trienes (CT) are often measured as indicators of free radical production. The oxidation of unsaturated fatty acids results in the formation of CD and CT. The CD and CT provide a marker of the early stages of lipid peroxidation (Halliwell and Gutteridge, 1985). It has been reported that the measurement of $C D$ and CT might be used as an index of stability of 
lipids in place of, or in addition to PV as presented by Shahidi (1997a) in his investigations. The CD and CT provide a marker of the early stages of peroxidation in studies for pure lipids and isolated lipoprotein (Dekkers et al., 1996).

Table 4 shows the relative increase in the $p$ anisidine value of canola oil treatments and control. $p$-anisidine value is used to measure the secondary products of lipid oxidation. This method determines the amount of aldehydes (principally 2-alkenals and 2, 4-alkadienals) in animal fats and vegetable oils. Aldehydes in oil and the $p$ - anisidine reagent react under acidic conditions to form a yellowish product (Shahidi, 1997a). It was noted that the control had significantly higher values of $p$ - anisidine as compared with those of stabilized canola oils. The $80 \%$ methanolic extract was found to be the most effective among all the extracts, as indicated by the lowest rise in the $p$-anisidine values of the CanolaME2 treatment. The highest $p$ - anisidine value of Canola-AE1 treatment demonstrated the lowest antioxidant potential of the $100 \%$ acetone extract of wheat bran. Chatha et al. (2006a) had reported a similar fashion of activity of the natural extracts of rice bran for the stabilization of sunflower oil regarding the $p$ - anisidine value as a parameter of assessment for the oxidation of the oil. A highly significant correlation is reported in the literature for $p$-anisidine value and flavor acceptability (Shahidi, 1997b). The results of the present analysis revealed that the methanolic extracts exhibited higher antioxidant activity than the acetone extracts of wheat bran. The more efficient extraction with $80 \%$ methanol might be attributed to the combined effect of water and methanol mixture due to enhanced polarity.

\section{CONCLUSION}

It could be concluded from the results of present study that the antioxidant activity of wheat bran extracts varied substantially depending on the nature of extracting solvents. For the use of an 80:20 blend of methanol, water can be recommended as an efficient extracting solvent for the extraction of the antioxidant components of wheat bran. The extracts derived from the wheat bran were found to be very effective towards suppressing the primary and secondary oxidation products in the investigated canola oil. The results of the present comprehensive analysis suggest that extracts of the wheat bran indigenous to Pakistan are a viable source of natural antioxidants and might be exploited for the stabilization of vegetable oils.

\section{REFERENCES}

Abdel-Aal E and Hucl P. 2003. Composition and stability of anthocyanins in blue-grained wheat, Journal of Agricultural and Food Chemistry 51, 2174-2180.

Amarowicz R, Karamac M and Chavan U. 2001. Influence of the extraction procedure on the antioxidative activity of lentil seed extracts in a beta-carotenelinoleate model system. Grasas y Aceites 52, 89-93.

Anwar F, Bhanger MI, Yasmeen S. 2003. Antioxidant activity of some natural extracts in corn oil. in Murata N, Yamada M, Nishida I, Okuyama H, Sekiya J \& Hajime W (Eds.) Advanced Research of Plant Lipids, 24-27, Kluwer Publishers, Netherlands.

Anwar F, Qayyum HMA, Hussain Al, lqbal S. 2010. Antioxidant activity of $100 \%$ and $80 \%$ methanol extracts from barley seeds (Hordeum vulgare L.): stabilization of sunflower oil. Grasas y Aceites 61, 237-243.

Baublis AJ, Clydesdale EM and Decker EA. 2000. Antioxidants in wheat-based breakfast cereals. Cereal Foods World 45, 71-74.

Chatha SAS, Anwar F, Manzoor M and Bajwa JR. 2006a. Evaluation of the antioxidant activity of rice bran extracts using different antioxidant assays. Grasas y Aceites 57, 328-335.

Chatha SAS, Hussain AI, Bajwa JR and Sagir M. 2006b. Antioxidant activity of different solvent extracts of rice bran at accelerated storage of sunflower oil. J. Food Lipids 13, 424-433.

Dekkers JC, Van Doornen LJP and Kemper HCG.1996. The role of antioxidant vitamins and enzymes in the prevention of exercise-induced muscles damage. Sports Medicine 21, 213-238.

Table 4

Relative increase in para-anisidine $\left(\varepsilon_{1 \mathrm{~cm}}\left(\lambda_{350 \mathrm{~nm}}\right)\right)$ of canola oil stabilized with wheat bran extracts at ambient storage

\begin{tabular}{cccccc}
\hline IPD & Ctrl & Canola-M.E1 & Canola-M.E2 & Canola-A.E1 & Canola-A.E2 \\
\hline 00 & $2.1 \pm 0.06^{\mathrm{a}}$ & $2.1 \pm 0.32^{\mathrm{a}}$ & $2.1 \pm 0.10^{\mathrm{a}}$ & $2.1 \pm 0.12^{\mathrm{a}}$ & $2.1 \pm 0.08^{\mathrm{a}}$ \\
15 & $8.0 \pm 0.29^{\mathrm{d}}$ & $4.7 \pm 0.49^{\mathrm{a}}$ & $4.2 \pm 0.28^{\mathrm{a}}$ & $6.9 \pm 0.52^{\mathrm{c}}$ & $5.9 \pm 0.34^{\mathrm{b}}$ \\
30 & $11.7 \pm 0.69^{\mathrm{d}}$ & $7.4 \pm 0.42^{\mathrm{a}}$ & $6.8 \pm 0.43^{\mathrm{a}}$ & $10.3 \pm 0.32^{\mathrm{c}}$ & $9.2 \pm 0.53^{\mathrm{b}}$ \\
45 & $15.1 \pm 0.64^{\mathrm{d}}$ & $10.2 \pm 0.44^{\mathrm{a}}$ & $9.6 \pm 0.73^{\mathrm{a}}$ & $13.5 \pm 0.59^{\mathrm{c}}$ & $12.1 \pm 0.74^{\mathrm{b}}$ \\
60 & $20.4 \pm 0.59^{\mathrm{d}}$ & $13.0 \pm 0.55^{\mathrm{a}}$ & $12.4 \pm 1.39^{\mathrm{a}}$ & $17.2 \pm 0.73^{\mathrm{c}}$ & $15.4 \pm 0.84^{\mathrm{b}}$ \\
75 & $30.3 \pm 1.86^{\mathrm{d}}$ & $17.3 \pm 0.69^{\mathrm{a}}$ & $15.9 \pm 1.59^{\mathrm{a}}$ & $25.4 \pm 0.84^{\mathrm{c}}$ & $22.1 \pm 1.61^{\mathrm{b}}$ \\
\hline
\end{tabular}

Values (mean \pm SD) are average of duplicate samples analyzed individually in triplicate. IPD: Incubation period in days. Ctrl.: Control sample (without wheat bran extract.). Canola-M.E1: Canola oil samples stabilized with 600ppm 100\% Methanolic Extract. Canola-M.E2: Canola oil samples stabilized with 600ppm 80\% Methanolic Extract. Canola-A.E1: Canola oil samples stabilized with 600ppm 100\% Acetone Extract. Canola-A.E2: Canola oil samples stabilized with 600ppm $80 \%$ Acetone Extract. Different letters in superscript in the same row represent significant $(p<0.05)$ difference. 
Halliwell B and Gutteridge JMC.1985. The chemistry of oxygen radicals and other oxygen derived species. Free radicals in biology and medicine (pp. 20-64). New York: Oxford University Press.

International Union of Pure and Applied Chemistry (IUPAC). 1987. Standard Methods for the Analysis of Oils, Fats and Derivatives, 7th Rev. edited by C. Paquot and A. Hautfenne, Blackwell Scientific, London. International Union of Pure and Applied Chemistry (IUPAC). 1987. Standard Method for the Analysis of Oils, Fats and Derivatives, 6th Ed., pp. 20-118, Pergamon Press, Oxford, U.K., New York, NY, Sydney, Australia.

lqbal S, Bhanger MI and Anwar F. 2005. Antioxidant properties and components of some commercially available varieties of rice bran in Pakistan. Food Chemistry 93, 265- 272.

Jeong SM, Kim SY, Kim DR, Jo SC, Man KC, Ahn DU and Lee SC. 2004. Effect of heat treatment on the antioxidant activity of extracts from citrus peals. $J$. Agric. Food Chem. 52, 3389-3393.

Kim KH, Tsao R, Yang R and Cui SW. 2006. Phenolic acid profiles and antioxidant activities of wheat bran extracts and the effect of hydrolysis conditions. Food Chem. 95, 466-473.

Mariod AA, Adamu HA, Ismail M and Ismail N. 2010. Antioxidative effects of stabilized and unstabilized defatted rice bran methanolic extracts on the stability of rice bran oil under accelerated conditions. Grasas y Aceites 61, 409-415.

McGinely L. 1991. Analysis and quality control for processing and processed fats. In: Analysis of Oilseeds, Fat and Fatty Food, Eds. Rossell JB; Printed, JLR, Elsevier Applied Science, London, New York, 1991, pp. 460-470.

Nystrom L, Makinen M, Lampi A M and Piironen V. 2005. Antioxidant activity of steryl ferulate extracts from rye and wheat bran. J. Agric. Food Chem. 53, 2503-2510.
Oryeneho SN and Hettiarachchy NS. 1992. Antioxidant activity of durum wheat bran. J. Agri. Food Chem. 49, 1496-1500.

Osawa T and Namiki M.1981. A novel type of antioxidant isolated from leaf wax of eucalyptus leaves. Agriculture and Biological Chemistry 45, 735-739.

Perumal S. and Becker K. 2003. Antioxidant properties of various solvent extracts of total phenolic constituents from three agroclimatic origins of Drumstick tree leaves. J. Agri. Food Chem. 51, 2144-2155.

Shahidi F. 1997a. Natural antioxidants: An over view. In: F.Shahidi (Ed.), Natural antioxidant, Chemistry, Health Effects and Applications, (pp. 1-10). Champaign, IL, USA: AOCS press.

Shahidi F. 1997b. Natural antioxidants: An over view. In: F. Shahidi (Ed.), Natural antioxidant, Chemistry, Health Effects and Applications, (pp. 44-46). Champaign, IL, USA: AOCS press.

Sultana B, Anwar F, Asi, M.R and Chatha SAS. 2008. Antioxidant potential of extracts from different agro wastes: Stabilization of corn oil. Grasas y Aceites 59, 205-217.

Wheat needs more attention for enhanced productivity. Retrieved May 09, 2005 from the World Wide. www. infopak.gov.pk/news/appnews/appnews2005/app. htm

Yen GC, Duh PD, Chuang DY. 2000. Antioxidant activity of anthraquinones and anthrone. Food Chem. 70, 307-315.

Zhou CJ, Pinson KI and Pleasure SJ. 2004. Severe defects in dorsal thalamic development in low-density lipoprotein receptor-related protein-6 mutants. $J$. Neurosci. 24, 7632-7639.

Zhou, K. and Yu, L. 2004. Antioxidant activities of bran extracts from "Trego" wheat grown at different locations. Journal of Agriculture and Food Chemistry 52, 1112-1117. 